(3) - 1947. Whitsun Field Meeting to the Central Weald. Proc. Geol. Assoc., lviii, 76.

(4) - 1948. Wealden Petrology. The Top Ashdown Pebble Bed and the Top Ashdown Sandstone. Quart. Journ. Geol. Soc., civ.

(5) Hayward, H. A., in Groves, A. W., 1931. The Unroofing of the Dartmoor Granite and the Distribution of its Detritus in the Sediments of Southern England. Quart. Journ. Geol. Soc., lxxxvii, 70,96 .

(6) Kirkaldy, J. F., and Bull, A. J., 1948. Note on the Section of Weald Clay Exposed at the Clock House Brickworks, Capel, Surrey. (Weald Research Committee.) Proc. Geol. Assoc.

\title{
CORRESPONDENCE
}

\section{THE CHARNIAN SYSTEM}

SiR,--In Professor Watts's posthumous memoir on Charnwood Forest, reviewed in your last number (ante, p. 118), there is one observation needing some correction.

On p. 115 of the Memoir reference is made to the views of Professor Kendall on a " porphyroid of Peldar type ... met with in a boring at the base of the Oxfordian at Bletchley". Kendall, however, also wrote in the same Final Report of the Royal Commission on Coal Supplies (pt. ix, p. 25) : "I suspect that some beds of greater geological age than Oxford Clay occur in the lower part of the Bletchley bore-hole." The Calvert boring confirmed this suspicion and made a new interpretation of Bletchley possible, with Lias resting on the Charnian (Davies and Pringle, Q.J.G.S., lxix, 332-3). As the Tremadoc Shales occur at Calvert in exactly the same position as the Charnian at Bletchley (only 12 miles away) it is highly probable that the latter are in situ and not boulders.

It is regrettable that the later interpretation of the Bletchley boring was overlooked in the Survey Memoir "On the thickness of Strata ..." (1916), where the Oxford Clay is given as 410 feet thick instead of 192 feet.

A. Morley Davies.

AMERSHAM,

Bucks.

25th May, 1948. 